\section{Evaluation of genotoxic and mutagenic effects of aqueous extract from aerial parts of Linaria genistifolia subsp. genistifolia}

\section{Recep Liman," Ŭgur Gürol Gökçe, Dilek Akyıl, Yasin Eren, Muhsin Konuk}

Biology Department, Faculty of Science and Literatures, Afyon Kocatepe University, Afyonkarahisar, Turkey.
Revista Brasileira de Farmacognosia Brazilian Journal of Pharmacognosy 22(3): 541-548, May/Jun. 2012

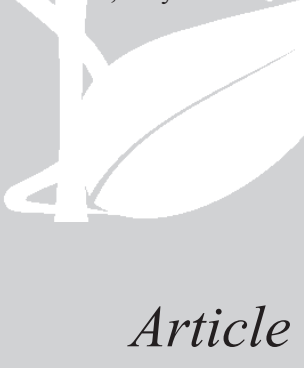

Article

Received 27 Jul 2011

Accepted 16 Dec 2011

\begin{abstract}
Genotoxic and mutagenic effects of aqueous extract from aerial parts Linaria genistifolia (L.) Mill. subsp. genistifolia, Plantaginaceae (Lg-ext) were investigated by using both Allium cepa root meristematic cells and bacterial reverse mutation assay in Salmonella typhimurium TA98 and TA100 with or without metabolic activation system (S9), respectively. In Allium root growth inhibition test, EC50 value was determined approximately $15 \mathrm{~g} / \mathrm{L}$ and $0.5 x E C 50$, EC50 and 2xEC50 concentrations of $L g$-ext were introduced to onion tuber roots and distilled water and methyl methane sulfonate (MMS, $10 \mathrm{ppm}$ ) used as a negative and positive control, respectively. The characteristic effect caused by tested preparations was an increase of mitotic index (MI) in $7.5 \mathrm{~g} / \mathrm{L}$ and $15 \mathrm{~g} / \mathrm{L}$ (except 24 and $96 \mathrm{~h}$ ) and simultaneous decrease of MI in $30 \mathrm{~g} / \mathrm{L}$ and in MMS. While stickiness, bridges, chromosome laggards and disturbed anaphase-telophase were observed in anaphase-telophase cells, c-metaphase, pro-metaphase, polyploidy and binuclear cells were observed in other cells. Lg-ext was not found to be mutagenic on S. typhimurium TA 98 and TA100 with or without S9. The results were also analyzed statistically by using SPSS for Windows, and Duncan's multiple range tests were performed respectively. These results indicate that Lg-ext exhibits genotoxic activity in A. cepa root meristematic cells but not mutagenic activity in Ames test system.
\end{abstract}

\begin{abstract}
Available online 3 Feb 2012
\end{abstract}

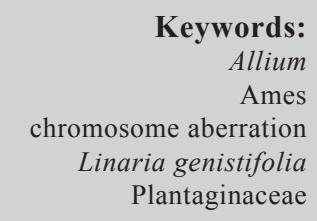

ISSN 0102-695X http://dx.doi.org/10.1590/S0102$695 \times 2012005000028$

\section{Introduction}

The genus Linaria, a well known genus of the family Plantaginaceae, is widely distributed throughout the northern hemisphere with its centre of distribution in the Mediterranean basin and eastern Asia. It comprises currently around 200 species, twenty of which are in Turkey popularly known as "nevruz otu" and nine of them endemics (Davis, 1978; Seçmen et al., 2000). Some Linaria species have been used in folk remedies for various purposes such as hemorrhoid, skin eruptions, sores, ulcers, diuretic, laxative, tonic, antiscorbutic, antidiabetic and to treat some vascular disorders. Dosage is critical and it should not be given to pregnant women, since the plant might be slightly toxic (San Feliciano et al., 1993; Baytop, 1999). Linaria species are reported to contain alkaloids, iridoid glucosides, flavonoids, aurones and diterpenoids (Otsuka, 1992; Ilieva et al., 1993; Bianco et al., 1996; Hua et al., 2002; Ahmad et al., 2006; Tundis et al., 2008; Ferhat et al., 2010). They contains a poisonous glucoside that is reported to be mildly poisonous to cattle (Moroshita, 1991).

Vicia faba, Tradescantia paludosa, Pisum sativum, Hordeum vulgare, Crepis capillaris and A. cepa are used to study of cytogenetic and genotoxic effect of plant extract or chemical(s). Among them, Allium test is one of the best-established test systems in order to determine the toxicity in the laboratories (Fiskesjö, 1985; Grant, 1992; Rank, 2003; Saxena et al., 2005; Konuk et al., 2007; Liman et. al., 2011). Because onions are easy to store and to handle, and also macroscopic and microscopic parameters can be observed easily. Moreover this system is well correlated with the data obtained from eukaryotic and prokaryotic systems (Fiskesjö, 1988).

Examining the mutagenicity of plant extract or chemical(s), Ames test, or the so-called Salmonellal microsome test, is widely used (Konuk et al., 2008; Uysal et al., 2010; Liman et al., 2010). This test can be carried out rapidly and cheaply and it is also one of the most reliable short-term bacterial test systems (Maron \& Ames, 1983; Mortelmans \& Zeiger, 2000). In this system, S. typhimurium mutant strains, obtained from S. typhimurium LT2 parental line in vitro, are employed (Ames et al., 1975).

The objective of this study was to investigate the genotoxic and mutagenic effects of $L g$-ext by employing both $A$. серa anaphase-telophase test and bacterial reverse mutation assay in S. typhimurium TA98 and TA100 strains 
with or without $\mathrm{S} 9$, respectively.

\section{Materials and Methods}

\section{Organisms}

The S. typhimurium test strains TA98 and TA 100 were obtained from Nuran Diril, Hacettepe University, Turkey. While TA98 were used for determining the frame shift, TA100 was used to determine the base pair exchange type of mutations. Allium cepa $(2 \mathrm{n}=16)$ onion bulbs, $25-30$ $\mathrm{mm}$ diameter, without any treatment, were purchased from a local supermarket.

\section{Chemicals}

S9 from Liver of rat (Sprague-Dawley), Bacto agar, nutrient broth no.2 (Oxoid), 2-aminoanthracene (2AA), $\beta$-nicotinamide-adenine dinucleotide phosphate ( $\beta$-NADP), glucose-6-phosphate (G6P), mitomycin-C (MMC), ampicillin and histidine were obtained from Sigma-Aldrich. Sodium azide (SA), citric acid monohydrate, sodium hydroxide, potassium chloride, sodium chloride, and dimethyl sulphoxide (DMSO) were purchased from Riedel. 4-Nitro- $O$-phenylenediamine (NPD) and 2-aminofluorene (2AF) were purchased from Fluka. Magnesium chloride, crystal violet, potassium phosphate and sodium ammonium phosphate were obtained from Merck.

\section{Plant collection and extraction}

The aerial parts of Linaria genistifolia (L.) Mill. subsp. genistifolia, Plantaginaceae, were collected from Başören Village, Afyonkarahisar, Turkey, in late-May 2010. The taxonomic identification of plant materials was confirmed by Dr Mehmet Temel, Department of Biology, Afyon Kocatepe University, Turkey. A voucher specimen was deposited at the Herbarium of Afyon Kocatepe University (number Kala 1410). Air dried and powdered aerial parts of the L. genistifolia subsp. genistifolia $(80 \mathrm{~g})$ were extracted with $1 \mathrm{~L}$ boiling water for $10 \mathrm{~min}$ (Sofowora, 1999). Both the decoctions and squeezed extracts were filtered with a $2.5-\mu \mathrm{m}$ filter (Whatman ${ }^{\circledR}$ no. 42) to remove the suspended particles and stored at $4{ }^{\circ} \mathrm{C}$ until usage. These were considered as the stock solutions and freshly prepared extracts were applied daily.

\section{Allium cepa anaphase-telophase test}

Prior to initiating the test, the outer scales of the bulbs and the dry bottom plate were removed without destroying the root primordia. In order to determine effective concentration (EC50), for each water sample, a series of six bulbs were placed in distilled water for 24 $\mathrm{h}$ and afterwards the best growing five bulbs exposed for four days (d) to the $L g$-ext solutions (10, 20, 40, 60 and 80 $\mathrm{g} / \mathrm{L}$, respectively) at room temperature $\left(\sim 21 \pm 4{ }^{\circ} \mathrm{C}\right)$. The test concentrations were renewed at every $24 \mathrm{~h}$ during the experiments. On the $5^{\text {th }}$ day, root lengths (lengths of ten roots from each bulb) were measured from both $\mathrm{Lg}$ ext exposed bulbs, and control group. EC50 value was considered as the concentration which retards the growth of root $50 \%$ when compared to the control.

In the determination of application doses, 2xEC50, EC50 and 0.5x EC5, positive (MMS, 10 ppm) and negative control group were used for 12, 24, 48, 72 and $96 \mathrm{~h}$. Fixation and staining of the root tip cells were carried out as reported earlier (Y1ld1z et al., 2009; Liman et al., 2010). The MI and the frequencies of chromosomal aberrations (CA) were carried out according to Saxena et al. (2005). For each test group, five slides (1 root tip/slide) were prepared by squashing root tips with $45 \%$ acetic acid. Slides were randomly coded and scored blindly. For MI, the different stages of mitosis were counted in a total of 5000-6000 cells (1000 cells/slide) per concentration, and expressed as a percentage. In chromosome aberration test, 100 cells in anaphase or telophase were examined for aberrations per slide if it is possible.

\section{Ames plate incorporation test}

Cytotoxic doses of $L g$-ext (3000, 1500, 750, $375,187.5$ and $93.75 \mathrm{mg} /$ plate) were determined by following the method of Dean et al. (1985).

Ames test was performed as a standard plate incorporation assay with $S$. typhimurium strains TA98 and TA100 with or without S9 (Maron \& Ames, 1983). Selection of the strains was based on the testing and strain selection strategies of Mortelmans \& Zeiger (2000). These strains were tested on the basis of associated genetic markers. For each tester strain, a specific positive control was always used to test the experimental flaws, if any. While 4-nitro-O-phenylenediamine (NPD) for TA 98 and sodium azide (SA) for TA100 were used as positive controls without S9, 2-aminofluorene (2AF) and 2-aminoanthracene (2AA) were used as positive controls with $\mathrm{S} 9$, respectively.

S9 mix $(500 \mu \mathrm{L})$ (or $500 \mu \mathrm{L}$ phosphate buffer), the test solution $(100 \mu \mathrm{L})$ for each concentration and a cell suspension $(100 \mu \mathrm{L})$ from an overnight culture $\left(1-2 \times 10^{9}\right.$ cells $\left./ \mathrm{mL}\right)$ were added to $2 \mathrm{~mL}$ top agar (kept at $45^{\circ} \mathrm{C}$ ) and vortexed for $3 \mathrm{~s}$. The entire mixture was overlaid on the minimal agar plate. The plates were incubated at $37^{\circ} \mathrm{C}$ for $72 \mathrm{~h}$ and then the revertant bacterial colonies on each plate were counted. Both the positive and negative controls (distilled water) were maintained concurrently. Samples were tested on triplicate plates in two independent parallel experiments. 


\section{Statistical analysis}

The data of root length, MI, mitotic phases, CA expressed as percentages, and the levels of significance in different treatment groups were analyzed statistically. For these, Duncan multiple range tests were performed by using one-way analysis of variance (ANOVA) on SPSS 15.0 version for Windows software both $A$. серa anaphase-telophase and Ames test.

\section{Results and Discussion}

Herbal medicine is still the mainstay of about $75-80 \%$ of the whole population, mainly in developing countries, for primary health care because of better cultural acceptability, better compatibility with the human body and fewer side effects. However, an increase in the usage of these plants in the developed world has been observed for a few years (Parekh et al., 2005). Therefore, knowledge of mutagenic and toxic effects of these plants become very important. Because many plants synthesize toxic substances for defense against viruses, bacteria and fungi etc. and these compounds could have potentially deleterious effects in humans. Neither phytochemical nor biological studies of L. genistifolia subsp. genistifolia have been previously reported on the topic studied.

Test systems to determine the genotoxicity and/ or mutagenicity can be divided into groups based on the biological systems employed and their genetic endpoint detected. Bioassays with prokaryotes enable the detection of agents that induce gene mutation and primary DNA damages. On the other hand, analyses with eukaryotes enable the detection of a greater damage extent, varying from gene mutations to chromosome damages and aneuploidies (Houk, 1992; Leme \& Marin-Morales, 2009). Using both pro- and eukaryotic test system make the results both strengthen and correlate to verify if the chemical(s) has/have really any bad effects on the genes.

Allium root growth test results are shown in Table 1. The EC50 was found to be approximately 15 $\mathrm{g} / \mathrm{L}$. It can be easily seen that the effect of $L g$-ext in Allium root growth was dose-dependent. Root growth decreased at all concentrations tested and yielded with statistically significant results $(p<0.05)$. In the meantime over $40 \mathrm{~g} / \mathrm{L}$ concentration, roots became dark colored, thicker and gel like formations. The inhibition of root growth generally related to apical meristematic activity (Webster \& Macleod, 1996), and to cell elongation during differentiation (Fusconi et al., 2006) and the appearance of stunted roots indicate the retardation of growth and cytotoxicity (Y1ldiz et al., 2009). As reported earlier, neoclerodane diterpenoids and flavonoids were isolated from Linaria saxatilis var. glutinosa by showing cytotoxic activity in different neoplastic cell cultures (Gordaliza et al., 1997). Tundis et al. (2005) determined the antiproliferative action of several flavones isolated from Linaria reflexa Desf., Plantaginaceae, against the large cell lung carcinoma cell line COR-L23, hepatocellular carcinoma cell line HepG-2, renal adenocarcinoma cell line $\mathrm{ACHN}$, amelanotic melanoma cell line C32 and colorectal adenocarcinoma cell line Caco-2, and reported that pectolinarigenin and some flavonoid glycosides like pectolinarin exhibited strong cytotoxic activity on CORL23 cell line with an IC50 value of 5.03 and $4.07 \mu \mathrm{M}$, respectively. Akkol \& Elçi (2009) suggested that the extracts of Linaria species (L. grandiflora, L. genistifolia subsp. confertiflora and L. aucheri) had analgesic and anti-inflammatory effects without toxicity.

Table 1. Results of the Allium root growth inhibition test.

\begin{tabular}{lccc}
\hline Doses $(\mathrm{g} / \mathrm{L})$ & $\begin{array}{c}\text { Average } \\
\text { length }(\mathrm{cm}) \pm \mathrm{SD}^{*}\end{array}$ & Growth (\%) & $\begin{array}{c}\text { Decrease (-) } \\
\text { in growth (\%) }\end{array}$ \\
\hline Control & $2.71 \pm 0.31 \mathrm{a}$ & 100 & - \\
10 & $1.86 \pm 0.18 \mathrm{~b}$ & 68.71 & 31.29 \\
20 & $1.09 \pm 0.17 \mathrm{c}$ & 40.26 & 59.74 \\
40 & $0.87 \pm 0.10 \mathrm{~d}$ & 32.21 & 67.79 \\
60 & $0.70 \pm 0.17 \mathrm{e}$ & 25.94 & 74.06 \\
80 & $0.51 \pm 0.12 \mathrm{f}$ & 18.93 & 81.07 \\
\hline
\end{tabular}

*Means with the same letter do not differ statistically at the level of 0.05. SD: Standard deviation.

Table 2 summarizes the effect of $L g$-ext on MI and mitotic phase in the root meristematic cells of $A$. cepa treated for 12, 24, 48, 72 and $96 \mathrm{~h}$. While at all concentrations used in the incubations of root in $7.5 \mathrm{~g} / \mathrm{L}$ and $15 \mathrm{~g} / \mathrm{L}$ (except 24 and $96 \mathrm{~h}$ ) increased MI, applications of $30 \mathrm{~g} / \mathrm{L}$ and MMS decreased MI compared to negative control at each exposure time. The highest values were obtained from $12 \mathrm{~h}$ examination of $7.5 \mathrm{~g} / \mathrm{L}$ concentrations of $L g$-ext ( $45.18 \pm 0.75)$, and the lowest one in $96 \mathrm{~h}$ applications of MMS (20.14 \pm 0.62$)$. The increased and decreased MI showed statistically significant results $(p<0.05)$. As stated by Fernandes et al. (2007), the cytotoxicity levels of an agent can be determined by the increase or decrease in the MI. MI lower than the negative control may indicate that the growth and development of exposed organisms have been affected by test compounds. On the other hand, MIs above those of the negative control are result of the induction of increased cell division, which may characterize an event detrimental to cells, leading to uncontrolled proliferation and even tumor formation (Hoshina et al., 2002). The increased cell proliferation activity can be the consequence of a reduction of the time necessary for DNA repair (Evseeva et al., 2003).

All concentrations of $L g$-ext used in the experiment caused changes in the percentage of particular phases' distribution in comparison to the control. The characteristic effect caused by tested preparations was an increase of prophase index except in $12 \mathrm{~h}$ at $30 \mathrm{~g} / \mathrm{L}$ 
Table 2. The effects of $L g$-ext on MI and mitotic phase of $A$. cepa root meristem cells.

\begin{tabular}{|c|c|c|c|c|c|c|}
\hline \multirow{2}{*}{ Concentration $(\mathrm{g} / \mathrm{L})$} & \multirow{2}{*}{ Counting cell number } & \multirow{2}{*}{$\mathrm{MI} \pm \mathrm{SE}^{*}$} & \multicolumn{4}{|c|}{ Mitotic Phases $(\%) \pm \mathrm{SE}^{*}$} \\
\hline & & & Prophase & Metaphase & Anaphase & Telophase \\
\hline Control- $12 \mathrm{~h}$ & 5102 & $30.04 \pm 0.59 \mathrm{a}$ & $88.92 \pm 1.31 \mathrm{a}$ & $1.49 \pm 0.28 \mathrm{a}$ & $3 \pm 0.68 \mathrm{a}$ & $6.59 \pm 1.05 \mathrm{ab}$ \\
\hline MMS-10 ppm & 5255 & $27.08 \pm 1.56 b$ & $75.26 \pm 2.44 \mathrm{~b}$ & $4.75 \pm 0.5 b$ & $10.48 \pm 1.45 \mathrm{~b}$ & $9.51 \pm 1.27 \mathrm{bc}$ \\
\hline 7.5 & 5148 & $45.18 \pm 0.75 \mathrm{c}$ & $91.49 \pm 1.36 \mathrm{a}$ & $1.73 \pm 0.39 \mathrm{a}$ & $1.4 \pm 0.23 \mathrm{a}$ & $5.38 \pm 1.65 \mathrm{a}$ \\
\hline 15 & 5150 & $33.34 \pm 0.47 \mathrm{~d}$ & $93.29 \pm 0.54 \mathrm{a}$ & $1.4 \pm 0.09 \mathrm{a}$ & $1.24 \pm 0.36 \mathrm{a}$ & $4.07 \pm 0.81 \mathrm{a}$ \\
\hline 30 & 5136 & $24.31 \pm 0.6 \mathrm{e}$ & $84.55 \pm 0.53 \mathrm{c}$ & $3.35 \pm 0.38 \mathrm{c}$ & $1.58 \pm 0.41 \mathrm{a}$ & $10.52 \pm 1.11 \mathrm{c}$ \\
\hline Control- $24 \mathrm{~h}$ & 5365 & $32.76 \pm 1.07 \mathrm{a}$ & $87.99 \pm 1.7 \mathrm{ab}$ & $4.72 \pm 1.48 \mathrm{a}$ & $1.14 \pm 0.3 \mathrm{a}$ & $6.15 \pm 0.83 a$ \\
\hline MMS-10 ppm & 5136 & $26.67 \pm 0.63 b$ & $86.89 \pm 1.27 \mathrm{a}$ & $3.57 \pm 0.31 \mathrm{a}$ & $3.24 \pm 0.42 b$ & $6.3 \pm 1.08 \mathrm{a}$ \\
\hline 7.5 & 5257 & $38.29 \pm 0.99 \mathrm{c}$ & $95.76 \pm 0.9 \mathrm{~d}$ & $0.56 \pm 0.19 b$ & $0.78 \pm 0.21 \mathrm{a}$ & $2.9 \pm 0.8 \mathrm{~b}$ \\
\hline 15 & 5210 & $28.49 \pm 0.53 b$ & $91.71 \pm 1.55 \mathrm{bc}$ & $1.45 \pm 0.38 b$ & $0.75 \pm 0.17 \mathrm{a}$ & $6.09 \pm 1.17 \mathrm{a}$ \\
\hline 30 & 5355 & $28.12 \pm 0.69 \mathrm{~b}$ & $93.16 \pm 0.49 \mathrm{~cd}$ & $0.4 \pm 0.09 \mathrm{~b}$ & $0.88 \pm 0.37 \mathrm{a}$ & $5.56 \pm 0.62 \mathrm{ab}$ \\
\hline Control- $48 \mathrm{~h}$ & 5229 & $29.14 \pm 1.04 \mathrm{a}$ & $84.43 \pm 0.67 \mathrm{a}$ & $3.25 \pm 0.56 \mathrm{a}$ & $4.69 \pm 0.5 \mathrm{a}$ & $7.63 \pm 0.42 \mathrm{a}$ \\
\hline MMS-10 ppm & 5177 & $24.27 \pm 0.83 b$ & $86.91 \pm 0.93 a$ & $3.45 \pm 0.46 \mathrm{a}$ & $3.86 \pm 0.36 \mathrm{a}$ & $5.78 \pm 0.69 \mathrm{ab}$ \\
\hline 7.5 & 5043 & $32.71 \pm 0.63 \mathrm{c}$ & $92.79 \pm 1.06 \mathrm{~b}$ & $3.52 \pm 0.95 \mathrm{a}$ & $2.24 \pm 0.93 b$ & $1.45 \pm 0.72 \mathrm{c}$ \\
\hline 15 & 5183 & $33.96 \pm 1.03 \mathrm{c}$ & $97.05 \pm 1.3 \mathrm{c}$ & $1.17 \pm 0.37 \mathrm{~b}$ & $0.51 \pm 0.23 \mathrm{c}$ & $1.27 \pm 0.86 \mathrm{c}$ \\
\hline 30 & 5204 & $25.56 \pm 1.23 b$ & $95.78 \pm 0.69 \mathrm{bc}$ & - & $0.13 \pm 0.03 \mathrm{c}$ & $4.09 \pm 0.73 b$ \\
\hline Control- $72 \mathrm{~h}$ & 5288 & $29.37 \pm 1.52 \mathrm{a}$ & $84.44 \pm 0.64 \mathrm{a}$ & $3.27 \pm 0.15 \mathrm{ab}$ & $2.98 \pm 0.56 \mathrm{a}$ & $9.31 \pm 0.47 \mathrm{a}$ \\
\hline MMS-10 ppm & 5064 & $25.18 \pm 1.37 \mathrm{~b}$ & $82.79 \pm 0.49 \mathrm{a}$ & $4.71 \pm 0.12 b$ & $3.21 \pm 0.67 \mathrm{a}$ & $9.29 \pm 0.44 \mathrm{a}$ \\
\hline 7.5 & 5151 & $37.75 \pm 0.36 \mathrm{c}$ & $89.4 \pm 0.61 b$ & $4.14 \pm 0.49 \mathrm{ab}$ & $4.72 \pm 0.25 b$ & $1.74 \pm 0.22 b$ \\
\hline 15 & 5088 & $33.01 \pm 0.81 \mathrm{c}$ & $93.67 \pm 0.97 \mathrm{c}$ & $2.55 \pm 0.58 \mathrm{a}$ & $0.67 \pm 0.22 \mathrm{c}$ & $3.11 \pm 0.26 \mathrm{~b}$ \\
\hline 30 & 5066 & $22.54 \pm 1.19 b$ & $93.56 \pm 1.86 \mathrm{c}$ & $2.73 \pm 1.11 \mathrm{a}$ & $1.32 \pm 0.37 \mathrm{c}$ & $2.39 \pm 1.06 \mathrm{~b}$ \\
\hline Control- $96 \mathrm{~h}$ & 5142 & $31.58 \pm 1.04 \mathrm{a}$ & $85.45 \pm 1.15 \mathrm{ab}$ & $2.76 \pm 0.42 \mathrm{a}$ & $3.01 \pm 0.46 \mathrm{a}$ & $8.77 \pm 1.1 \mathrm{a}$ \\
\hline MMS-10 ppm & 5159 & $20.14 \pm 0.62 b$ & $82.92 \pm 1.62 \mathrm{a}$ & $4.61 \pm 0.32 b$ & $3.53 \pm 0.51 \mathrm{ab}$ & $8.92 \pm 1.16 \mathrm{a}$ \\
\hline 7.5 & 5168 & $35.45 \pm 1.38 \mathrm{c}$ & $88.69 \pm 0.77 b$ & $2.79 \pm 0.46 \mathrm{a}$ & $4.85 \pm 0.92 b$ & $3.65 \pm 0.66 \mathrm{~b}$ \\
\hline 15 & 5200 & $26.27 \pm 0.63 \mathrm{~d}$ & $94.54 \pm 1.1 \mathrm{c}$ & $1.03 \pm 0.34 \mathrm{c}$ & $0.66 \pm 0.27 \mathrm{c}$ & $3.76 \pm 0.96 \mathrm{~b}$ \\
\hline 30 & 5170 & $24.82 \pm 0.85 \mathrm{~d}$ & $96.61 \pm 0.53 \mathrm{c}$ & - & $0.24 \pm 0.16 \mathrm{c}$ & $3.13 \pm 0.39 b$ \\
\hline
\end{tabular}

*Means with the same letter do not differ statistically at the level of 0.05 in each group. SE: Standard Error.

and simultaneous decrease of anaphase index except in 72 and $96 \mathrm{~h}$ at $7.5 \mathrm{~g} / \mathrm{L}$ and telophase index except in $12 \mathrm{~h}$ at $30 \mathrm{~g} / \mathrm{L}$. This might be an indication of the blockage of chfr point (control point between prophase/metaphase). Scolnic \& Halazonetis (2000) reported that chrf defines a checkpoint that delays entry into metaphase in response to mitotic stress. Most of the increased and decreased phase index showed statistically significant results $(\mathrm{p}<0.05)$.

In the $A$. серa anaphase-telophase chromosome aberration test conducted with root meristematic cells of $A$. cepa as shown in Table 3. The most frequent abnormalities were stickiness, anaphase bridges, chromosome laggards and disturbed anaphase-telophase in anaphase-telophase cells. The effect of $L g$-ext concentration on CA was significantly different $(p<0.05)$ except in $12 \mathrm{~h}$ at 7.5 $\mathrm{g} / \mathrm{L}$ compared to the negative control. Analysis of the chromosomes showed that $7.5 \mathrm{~g} / \mathrm{L}$ of $L g$-ext concentration except in 12 and $24 \mathrm{~h}$ and $15 \mathrm{~g} / \mathrm{L}$ of $L g$-ext concentration in 12 and $96 \mathrm{~h}$ induced chromosomal aberrations but other Lg-ext concentrations decreased chromosomal aberrations. No aberration was recorded in the chromosome of $A$. cepa exposed to the $30 \mathrm{~g} / \mathrm{L}$ of $L g$-ext concentration in 72 and
$96 \mathrm{~h}$. Stickiness (especially at $7.5 \mathrm{~g} / \mathrm{L}$ in $48 \mathrm{~h}$ ) indicates highly irreversible type toxic effect of $L g$-ext, and its occurrences during the study could be because of subchromatid linkage between chromosomes (Mc-Gill et al., 1974; Chauhan et al., 1986; Kovalchuk et al., 1998; Ajay \& Sarbhoy, 1988). Anaphase bridges could happen during the translocation of the unequal chromatid exchange or due to dicentric chromosome presence or due to the breakage and fusion of chromosomes and chromatids. This bridges cause structural chromosome mutations (El-Ghamery et al., 2000; Luo et al., 2004). Disturbed anaphase-telophase (especially at $15 \mathrm{~g} / \mathrm{L}$ in $12 \mathrm{~h}$ and at $7.5 \mathrm{~g} / \mathrm{L}$ in $72 \mathrm{~h}$ ) and chromosome laggards could occur by the effect of $L g$-ext on microtubule formations (Amer \& Ali, 1986; Kumari et al., 2009). Such spindle malfunctioning may arise due to inhibition of tubulin polymerization (Kuriyama \& Sakai, 1974). The occurrence of chromosome laggards at anaphase was due to the failure of the chromosomes or acentric chromosome fragments to move to either of the pole.

In addition to these anomalies, others (c-metaphase, pro-metaphase, polyploidy and binuclear 
Table 3. Percentage of chromosome aberrations of $L g$-ext in different times and concentrations obtained for the $A$. cepa anaphasetelophase test.

\begin{tabular}{|c|c|c|c|c|c|c|c|c|c|c|c|c|}
\hline \multirow{2}{*}{$\begin{array}{l}\text { Concentration } \\
(g / L)\end{array}$} & \multicolumn{6}{|c|}{ Anaphase-telophase anomalies \% } & \multicolumn{6}{|c|}{ Other Anomalies \% } \\
\hline & $\mathrm{CCN}$ & $\mathrm{S}$ & $\mathrm{AB}$ & $\mathrm{CL}$ & DAT & $\mathrm{TA} \pm \mathrm{SE}^{*}$ & $\mathrm{CCN}$ & $\mathrm{CM}$ & PM & $\mathrm{P}$ & $\mathrm{BNC}$ & $\mathrm{TA} \pm \mathrm{SE}^{*}$ \\
\hline Control- $12 \mathrm{~h}$ & 400 & 3.84 & 11.69 & 14.21 & 1.4 & $31.14 \pm 2.5 \mathrm{a}$ & 5102 & 0.06 & 0.06 & - & 0.1 & $0.21 \pm 0.06 \mathrm{a}$ \\
\hline MMS-10 ppm & 500 & 3.6 & 3.8 & 10.6 & 7.6 & $25.6 \pm 1.28 \mathrm{a}$ & 5255 & 0.17 & 0.4 & 0.04 & 0.02 & $0.63 \pm 0.12 b$ \\
\hline 7.5 & 371 & 10.84 & 2.51 & 2.65 & 14 & $30 \pm 2.55 \mathrm{a}$ & 5148 & 0.08 & 0.17 & - & 0.02 & $0.27 \pm 0.07 \mathrm{a}$ \\
\hline 15 & 429 & 2.52 & 2.04 & 10.2 & 26 & $40.76 \pm 1.48 b$ & 5150 & 0.07 & 0.06 & 0.02 & - & $0.15 \pm 0.03 \mathrm{a}$ \\
\hline 30 & 291 & 1.93 & 2.36 & 4.55 & 7.4 & $16.24 \pm 1.99 \mathrm{c}$ & 5136 & 0.04 & 0.07 & - & - & $0.11 \pm 0.03 \mathrm{a}$ \\
\hline Control- $24 \mathrm{~h}$ & 500 & 10.26 & 4.64 & 17.24 & 14.4 & $46.55 \pm 0.7 \mathrm{a}$ & 5365 & 0.5 & 0.63 & - & - & $1.13 \pm 0.15 \mathrm{a}$ \\
\hline MMS-10 ppm & 500 & 19 & 3 & 15 & 19.2 & $56.2 \pm 1.82 \mathrm{~b}$ & 5136 & 0.07 & 0.02 & - & 0.22 & $0.31 \pm 0.08 \mathrm{~b}$ \\
\hline 7.5 & 252 & 8.27 & 0.77 & - & 4.94 & $13.97 \pm 1.11 \mathrm{c}$ & 5257 & - & 0.06 & - & 0.05 & $0.11 \pm 0.05 b$ \\
\hline 15 & 152 & 1.32 & 0.71 & 2.26 & 5.68 & $9.98 \pm 0.73 d$ & 5210 & 0.03 & 0.04 & - & - & $0.07 \pm 0.03 \mathrm{~b}$ \\
\hline 30 & 137 & 1.82 & 0.42 & 0.8 & 5.77 & $8.82 \pm 0.86 \mathrm{~d}$ & 5355 & - & 0.03 & - & 0.04 & $0.07 \pm 0.04 \mathrm{~b}$ \\
\hline Control- $48 \mathrm{~h}$ & 500 & 10.99 & 5.7 & 19.59 & 9.99 & $46.25 \pm 1.46 \mathrm{a}$ & 5229 & 0.08 & 0.03 & - & - & $0.11 \pm 0.04 \mathrm{a}$ \\
\hline MMS-10 ppm & 500 & 7.82 & 8.65 & 13.49 & 26.27 & $56.22 \pm 1.61 \mathrm{~b}$ & 5177 & 0.2 & 0.02 & - & 0.32 & $0.54 \pm 0.11 \mathrm{a}$ \\
\hline 7.5 & 389 & 15.78 & 14.83 & 12.2 & 19.19 & $62.01 \pm 3.31 \mathrm{~b}$ & 5043 & 0.1 & 0.6 & 0.02 & - & $0.72 \pm 0.46 \mathrm{a}$ \\
\hline 15 & 289 & 0.4 & 1.6 & 1 & 2.4 & $5.4 \pm 0.97 \mathrm{c}$ & 5183 & 0.12 & 0.32 & 0.02 & - & $0.46 \pm 0.16 \mathrm{a}$ \\
\hline 30 & 196 & 0.38 & - & - & 1.82 & $2.20 \pm 1.76 \mathrm{c}$ & 5204 & - & - & - & - & - \\
\hline Control- $72 \mathrm{~h}$ & 500 & 14.6 & 4 & 10.6 & 10.2 & $39.4 \pm 3.14 \mathrm{a}$ & 5288 & 0.09 & - & - & - & $0.09 \pm 0.05 \mathrm{a}$ \\
\hline MMS-10 ppm & 500 & 11.69 & 5.55 & 7.42 & 19.16 & $43.82 \pm 1.22 \mathrm{~b}$ & 5064 & 0.14 & - & 0.01 & - & $0.15 \pm 0.03 \mathrm{a}$ \\
\hline 7.5 & 352 & 7.91 & 2.82 & 5.87 & 36.28 & $59.87 \pm 2.94 \mathrm{c}$ & 5151 & 0.23 & 0.41 & 0.04 & - & $0.68 \pm 0.1 \mathrm{~b}$ \\
\hline 15 & 301 & 3.47 & 11.13 & 4.23 & 9.75 & $28.58 \pm 1.84 \mathrm{~d}$ & 5088 & - & 0.49 & - & - & $0.48 \pm 0.08 \mathrm{~b}$ \\
\hline 30 & - & - & - & - & - & - & 5066 & 0.08 & 0.01 & - & - & $0.09 \pm 0.02 \mathrm{a}$ \\
\hline Control- $96 \mathrm{~h}$ & 500 & 3.82 & 2.02 & 6.63 & 6.67 & $19.13 \pm 2.37 \mathrm{a}$ & 5142 & 0.1 & 0.03 & - & - & $0.13 \pm 0.03 \mathrm{a}$ \\
\hline MMS-10 ppm & 500 & 22.2 & 1.4 & 5.4 & 20.2 & $49.2 \pm 2.26 \mathrm{~b}$ & 5159 & 0.08 & 0.01 & - & - & $0.09 \pm 0.02 \mathrm{a}$ \\
\hline 7.5 & 170 & 2.68 & 10.09 & 1.03 & 17.1 & $30.9 \pm 4.07 \mathrm{c}$ & 5168 & 0.1 & 0.21 & 0.02 & 0.02 & $0.35 \pm 0.08 \mathrm{~b}$ \\
\hline 15 & 144 & 4.16 & 3.54 & - & 19.48 & $27.18 \pm 0.98 \mathrm{c}$ & 5200 & - & - & - & 0.04 & $0.04 \pm 0.02 \mathrm{a}$ \\
\hline 30 & - & - & - & - & - & - & 5170 & - & - & - & - & - \\
\hline
\end{tabular}

*Means with the same letter do not differ statistically at the level of 0.05 in each group. SE: Standard Error, CCN: Counting Cell Numbers, S: Stickiness, AB: Anaphase Bridge, CL: Chromosome Laggards, DAT: Disturbed Anaphase-Telophase, TA: Total Anomalies, PM: Pro-metaphase, CM: c-metaphase, P: Polyploidy, BNC: Binuclear cell.

cell) were also observed. While the lowest anomalies were observed $0.04 \pm 0.02 \%$ at the 15 in $12 \mathrm{~h}$, the highest ones were observed $0.72 \pm 0.46 \%$ at $7.5 \mathrm{~g} / \mathrm{L}$ in $48 \mathrm{~h}$. Statistically significant $(p<0.05)$ frequencies of other anomalies were recorded in $12 \mathrm{~h}$ at $7.5 \mathrm{~g} / \mathrm{L}$, all $24 \mathrm{~h}$ applications, in $72 \mathrm{~h}$ at 15 and $30 \mathrm{~g} / \mathrm{L}$, and also in $96 \mathrm{~h}$ at $7.5 \mathrm{~g} / \mathrm{L}$. It was not observed any anomalies in 48 and $96 \mathrm{~h}$ at $30 \mathrm{~g} / \mathrm{L}$. C-metaphase, a possibly reversible effect, might occur due to disturbed microtubules by $L g$-ext and could be induced aneuploidies (Fiskesjö, 1988; Shahin \& El-Amodi, 1991; Odeigah et al., 1997). Polyploidy cells can occur due to the lack of fragmoplast that prevents the formation of the daughter cells (Vidakovivé-Cifrek et al., 2002; Fernandes et al., 2007). Binuclear cells are accepted as the inhibition of cytokinesis in any control points of the cellular cycle (Ateeq et al., 2002).

The results from the Ames test are shown in Table 4. The interpretation of the Ames test results for genotoxicity testing of chemicals United States Environmental Protection Agency (USEPA, 1996) methods were followed. According to the guideline, a mutagenic potential is assumed, if the revertant frequency is 2.0 or higher over the solvent control or dose-related increase in the number of revertant colonies in one or more strains (Mortelmans \& Zeiger, 2000). Noncytotoxic doses of the $L g$-ext tested were determined firstly. The results obtained suggested that all tested concentrations were not determined as cytotoxic. The average revertant colony numbers in negative control were $34.8 \pm 1.48$ for TA98 and $147.6 \pm 12.05$ for TA100 with S9 and $32 \pm 3.31$ and $105 \pm 7.21$ without S9 respectively. Spontaneous revertants were within the normal values for the four strains examined. While application of S9 in TA98 was decreased revertant colony numbers, application of S9 in TA100 was increased revertant colony numbers. On the contrary, the plates with the positive control mutagens 
(SA, 2AF, 2AA and NPD) showed significant increases relative to the spontaneous mutation rate in the two tested strains. While the highest value observed was in the TA100 with S9 at $750 \mu \mathrm{g} /$ plate concentration of Lg-ext (216.4 \pm 11.78$)$, and the lowest value was in the TA98 with S9 at $750 \mu \mathrm{g} /$ plate concentration of $L g$-ext (25.6 \pm 1.14$)$. Most of the results, increasing or decreasing relative to negative control group, were not statistically significant at $p<0.05$ (Duncan test) in examined strains In order to establish a dose-response relationship, 5 different concentrations of $L g$-ext were tested, and no induced revertants were observed along the dose range tested in either with or without S9 with two strains. The results of the present study showed that all applications of $L g$-ext were not found to be mutagenic S. typhimurium TA98 and TA100 with or without S9.

In conclusion, our results indicate that $L g$-ext was found cytotoxic and genotoxic in Allium test but not found mutagenic in Ames test. Although some Linaria species have been used in folk remedies for various purposes, they should be used with caution, always following the traditional methods of preparation exactly. Further studies are necessary to determine the active ingredient or compound(s) of Linaria genistifolia subsp. genistifolia and should be tested in other biological test systems to obtain definitive conclusions on their cytotoxic, genotoxic and mutagenic potential.

\section{Acknowledgements}

The authors wish to thank Afyon Kocatepe University Scientific Research Committee for supporting this study financially (Project No: 11.FEN.BIL.16) and Dr. M. Temel for the identification of the plant.

\section{References}

Ahmad VU, Kousar F, Zubair M, Khan A, Ali MS, Choudhary MI, Sener B 2006. A new iridoid glycoside from Linaria genestifolia. Fitoterapia 77: 12-14.

Ajay KL, Sarbhoy RK 1988. Cytogenetic studies on the effect of some chlorinated pesticides. Cytologia 53: 427-436.

Akkol EK, Elci D 2009. Antinociceptive and anti-inflammatory activities of some Linaria species from Turkey. Pharm. Biol 47: 188-194.

Amer SM, Ali EM 1986. Cytological effects of pesticides. XVII. Effect of the insecticide dichlorvas on root mitosis of Vicia faba. Cytologia 51: 21-25.

Ames B, Mccann J, Yamasaki E 1975. Methods for detecting carcinogens and mutagens with the Salmonellal mammalian microsome mutagenicity test. Mutat Res 31: 347-364.

Ateeq B, Adul Farrah M, Ali MN, Ahmad W 2002. Clastogenicity of pentachlorophenol, 2-4-D and butachlor evaluated by Allium Root Tip Test. Mutat Res 514: 105-113.

Baytop T 1999. Therapy with Medicinal Plants in Turkey, Past and Present, Nobel Tip Kitapevi, Istanbul.

Bianco A, Guiso M, Mazzei RA, Piccioni F, Nicoletti M, Serafini M, Ballero M 1996. 69-O-Acetylantirrhinoside, a new iridoid glucoside from Linaria flava subsp. sardoa. Fitoterapia 67: 364-366.

Chauhan LKS, Dikshith TSS, Sundararaman V 1986. Effect of deltamethrin on plant cells. I. cytological effects on the root meristem cells of Allium cepa. Mutat Res 171: 2530.

Davis PH 1978. Flora of Turkey and the East Aegean Island. vol. 6. University press, Edinburgh, 825 pp.

Dean BJ, Brooks TM, Hodson-Walker G, Hutson DH 1985.

Table 4. Mutagenicity of $L g$-ext towards S. typhimurium TA98 and TA100 strain with or without S9.

\begin{tabular}{|c|c|c|c|c|c|}
\hline \multirow{3}{*}{ Agent } & \multirow{3}{*}{ Amount ( $\mu \mathrm{g} /$ plate $)$} & \multicolumn{4}{|c|}{ No of $\mathrm{His}^{+}$Revertants/plate Mean $\pm \mathrm{SD}^{*}$} \\
\hline & & \multicolumn{2}{|c|}{ TA98 } & \multicolumn{2}{|c|}{ TA100 } \\
\hline & & $-\mathrm{S} 9$ & + S9 & $-\mathrm{S} 9$ & + S9 \\
\hline \multirow{6}{*}{$L g$-ext } & 3000 & $30.2 \pm 3.42 \mathrm{a}$ & $28.6 \pm 1.81 \mathrm{a}$ & $110.6 \pm 8.56 \mathrm{a}$ & $214 \pm 10.41 \mathrm{a}$ \\
\hline & 1500 & $31 \pm 3.67 \mathrm{a}$ & $28 \pm 1.58 \mathrm{a}$ & $111.4 \pm 4.33 \mathrm{a}$ & $184 \pm 7.44 \mathrm{a}$ \\
\hline & 750 & $30 \pm 2.73 \mathrm{a}$ & $25.6 \pm 1.14 \mathrm{a}$ & $105,2 \pm 2.38 \mathrm{a}$ & $216,4 \pm 11.78 \mathrm{a}$ \\
\hline & 375 & $31.6 \pm 1.81 \mathrm{a}$ & $27.2 \pm 0.83 \mathrm{a}$ & $109 \pm 8.09 \mathrm{a}$ & $177,8 \pm 6.3 \mathrm{a}$ \\
\hline & 187.5 & $29.4 \pm 3.2 \mathrm{a}$ & $27 \pm 1.58 \mathrm{a}$ & $108 \pm 6.72 \mathrm{a}$ & $183,6 \pm 21 \mathrm{a}$ \\
\hline & 93.75 & $31.2 \pm 2.38 \mathrm{a}$ & $26.2 \pm 3.56 \mathrm{a}$ & $102.2 \pm 4.43 \mathrm{a}$ & $112,4 \pm 10.6 \mathrm{a}$ \\
\hline Control & & $32 \pm 3.31 \mathrm{a}$ & $34.8 \pm 1.48 \mathrm{a}$ & $105 \pm 7.21 \mathrm{a}$ & $147.6 \pm 12.05 \mathrm{a}$ \\
\hline SA & 10 & & & $1646.2 \pm 112.34 \mathrm{~b}$ & \\
\hline $2 \mathrm{AA}$ & 5 & & & & $2279.2 \pm 108.72 b$ \\
\hline $2 \mathrm{AF}$ & 200 & & $885.6 \pm 81.15 b$ & & \\
\hline NPD & 200 & $1380.4 \pm 114.61 b$ & & & \\
\hline
\end{tabular}


Genetic toxicology testing of 41 industrial chemicals. Mutat Res 153: 57-77.

El-Ghamery AA, El-Nahas AI, Mansour MM 2000. The action of atrazine herbicide as an indicator of cell division on chromosomes and nucleic acid content in root meristems of Allium cepa and Vicia faba. Cytologia 65: 277-287.

Evseeva TI, Stanislav A, Geras'kin I, Shuktomova I 2003. Genotoxicity and toxicity assay of water sampled from a radium production industry storage cell territory by means of Allium-Test. J Environ Radioactiv 68: 235248.

Ferhat M, Harkat H, Lavaud C, Haba H, Long C, Benkhaled M 2010. Iridoids and flavonoid from Linaria aegyptiaca (L.) Dum. subsp. fruticosa. Biochem Sys Ecol 38: 833835.

Fernandes TCC, Mazzeo DEC, Marin-Morales MA 2007. Mechanism of micronuclei formation in polyploidizated cells of Allium cepa exposed to trifluralin herbicide. Pestic Biochem Phys 88: 252-259.

Fiskesjö G 1985. The Allium Test as standart in enviromental monitoring. Hereditas 102: 99-112.

Fiskesjö G 1988. The Allium Test-an alternative in environmental studies: The relative toxicity of metal ions. Mutat Res 197: 243-260.

Fusconi A, Repetto O, Bona E, Massa N, Gallo C, DumasGaudot E, Berta G 2006. Effect of cadmium on meristem activity and nucleus ploidy in roots of Pisum sativum L. cv. Frisson seedlings. Env Exp Bot 58: 253-260.

Gordaliza M, Miguel Del Corral JM, Luz de la puente M, Garcia-Grávalos MD, San Feliciano A 1997. Cytotoxic activity of neo-clerodane diterpenoids. Bioorg Med Chem Lett 7: 1649.

Grant WF 1992. Cytogenetics studies of agricultural chemicals in plants in: genetic toxicology an agricultural perspective. Plenum Pres, Newyork, p. 335-378.

Hoshina MM 2002. Evaluation of a possible contamination of the waters of the Claro River-Municipality of Rio Claro, part of the Corumbataí River Basin, with the mutagenicity tests using Allium cepa. State University of São Paulo, Rio Claro, SP. (İn Portuguese).

Houk VS 1992. The genotoxicity of industrial wastes and effluents - A review. Mutat Res 277: 91-138.

Hua H, Cheng M, Li X, Pei Y 2002. A new pyrroloquinazoline alkaloid from Linaria vulgaris. Chem Pharm Bull 50: 1393-1394.

Ilieva E, Handjieva N, Spassov S, Popov S 1993. 5-Oallosylantirrhinoside from Linaria species. Phytochemistry 32: 1068-1070.

Konuk M, Akyıl D, Liman R, Özkara A 2008. Examination of the mutagenic effects of some pesticides. Fresen Environ Bull 17: 439-442.

Konuk M, Liman R, Cigerci IH 2007. Determination of genotoxic effect of boron on Allium cepa root meristematic cells. Pakistan J of Bot 39: 73-79.
Kovalchuk O, Arkhipov I, Telyuk A, Hohn P, Kovalchuk L 1998. The Allium cepa chromosome aberration test reliably measures genotoxicity of soils of inhabited areas in the Ukraine contaminated by the Chernobyl accident. Mutat Res 415: 47-57.

Kumari M, Mukherjee A, Chandrasekaran N 2009. Genotoxicity of silver nanoparticles in Allium cepa. Sci Total Environ 407: 5243-5246.

Kuriyama R, Sakai H 1974. Role of Tubulin-Sh groups in polymerization to microtubules. Functional-Sh groups in tubulin for polymerization. $J$ Biochem 76: 651-654.

Leme DM, Marin-Morales MA 2009. Allium cepa Test in environmental monitoring: A review on its application. Mutat Res 682: 71-81.

Liman R, Aky1l D, Eren Y, Konuk M 2010. Testing of the mutagenicity and genotoxicity of metolcarb by using both Ames/Salmonella and Allium Test. Chemosphere 80: 1056-1061.

Liman R, Cigerci IH, Aky1l D, Eren Y, Konuk M 2011. Determination of genotoxicity of fenaminosulf by Allium and Comet Tests. Pestic Biochem Phys 99: 6164.

Luo LZ, Werner KM, Gollin SM, Saunders WS 2004. Cigarette smoke induces anaphase bridges and genomic imbalances in normal cells. Mutat Res 554: 375-385.

Maron DH, Ames BN 1983. Revised methods for the Samonella typhimurium mutagenicity test. Mutat Res 113: 173215.

Mc-Gill M, Pathak S, Hsu TC 1974. Effects of ethidium bromide on mitosis and chromosomes: A possible materyal basis chromosomes stickiness. Chromosoma 47: 157-167.

Moroshita DW 1991. Dalmatian toadflax, yellow toadflax, black henbane, and tansymustard: importance, distribution, and control. p. 399-408. In: James LF, Evans JO, Ralphs MH, Child RD (eds), Noxious range weeds. Westview Press, Boulder, San Francisco and Oxford.

Mortelmans K, Zeiger E 2000. The Ames Salmonellal microsome mutagenicity assay. Mutat Res 445: 2960.

Odeigah PGC, Nurudeen O, Amund OO 1997. Genotoxicity of oil field wastewater in Nigeria, Hereditas 126: 161167.

Otsuka HJ 1992. Isolation of isolinariin A and B, new flavonoid glycosides from Linaria japonica. J Nat Prod 55: 12521255.

Parekh J, Jadeja D, Chanda S 2005. Efficacy of aqueous and methanol extracts of some medicinal plants for potential antibacterial activity. Turk J Biol 29: 203-210.

Rank J 2003. The method of Allium anaphase-telophase chromosome aberration assay. Ekologiia 1: 38-42.

San Feliciano A, Gordaliza M, Miguel del Corral JM, de la Puente ML 1993. Neo-clerodane diterpenoids from roots of Linaria saxatilis var. glutinosa. Phytochemistry 33: 631-633. 
Saxena PN, Chauhan LKS, Gupta SK 2005. Cytogenetic effects of commercial formulation of cypermethrin in root meristem cells of Allium sativum: Spectroscopic basis of chromosome damage. Toxicology 216: 244-252.

Scolnic D, Halazonetis T 2000. Chfr defines a mitotic stress checkpoint that delays entry into metaphase. Nature 406: 430-435.

Seçmen Ö, Gemici Y, Görk G, Bekat L, Leblebici E 2000. Tohumlu Bitkiler Sistematiği, Ege Ünv. Fen Fak. Kitaplar Serisi No 116, VI. Baskı, Ege Ünv. Basımevi, İzmir.

Shahin SA, El-Amoodi KHH 1991. Induction of numberical chromosomal aberrations during DNA synthesis using fungicides nimrod and rubigan-4 in root tips of Vicia faba L. Mutat Res 261: 169-176.

Sofowora A 1999. The state of medicinal plants research in Nigeria. In: Proceeding of workshop. Held at Ile-Ife, Nigeria; 1-373.

Tundis R, Deguin B, Loizzo MR, Bonesi M, Statti GA, Tillequin F, Menichini F 2005. Potential antitumor agents: Flavones and their derivatives from Linaria reflexa Desf. Bioorg Med Chem Lett 15: 4757-4760.

Tundis R, Deguin B, Dodaro D, Statti GA, Tillequin F, Menichini F 2008. Iridoid glycosides from Linaria multicaulis (L.) Miller subsp. multicaulis (Scrophulariaceae). Biochem Syst Ecol 36: 142-145.

United States Environmental Protection Agency (USEPA) 1996. United States Environmental Protection Agency
(USEPA), Health Effects Tests Guidelines: OPPTS.

Uysal A, Durak Y, Aladağ MO 2010. Investigation of mutagenic effects of some plant growth regulators on Salmonellal Microsome Test System. Fresen Environ Bull 19: 21702175.

Vidakovivé-Cifrek Z, Pavlica M, Regula I, Papers D 2002. Cytogenetic damage in shallot (Allium cepa) root meristems induced by oil industry "High-Density Brines". Environ Cont Toxicol 43: 284-291.

Webster PL, Macleod RD 1996. The root apical meristem and its magrin, In: Waishel Y, Eshel A, Kafkafi U (eds.), Plant roots. the hidden half ( $2^{\text {nd }}$ ed.), Marcel Dekker, New York, p. 51-76.

Yildız M, Cigerci IH, Konuk M, Fidan AF, Terzi H 2009. Determination of genotoxic effects of copper sulphate and cobalt chloride in Allium cepa root cells by chromosome aberration and comet assays. Chemosphere 75: 934-938.

\section{*Correspondence}

Recep Liman

Biology Department, Faculty of Science and Literatures, Afyon Kocatepe University,

ANS Campus, Gazligol Yolu, 03200-Afyonkarahisar/Turkey rliman@aku.edu.tr Tel: +902722281339

Fax: +902722281235 